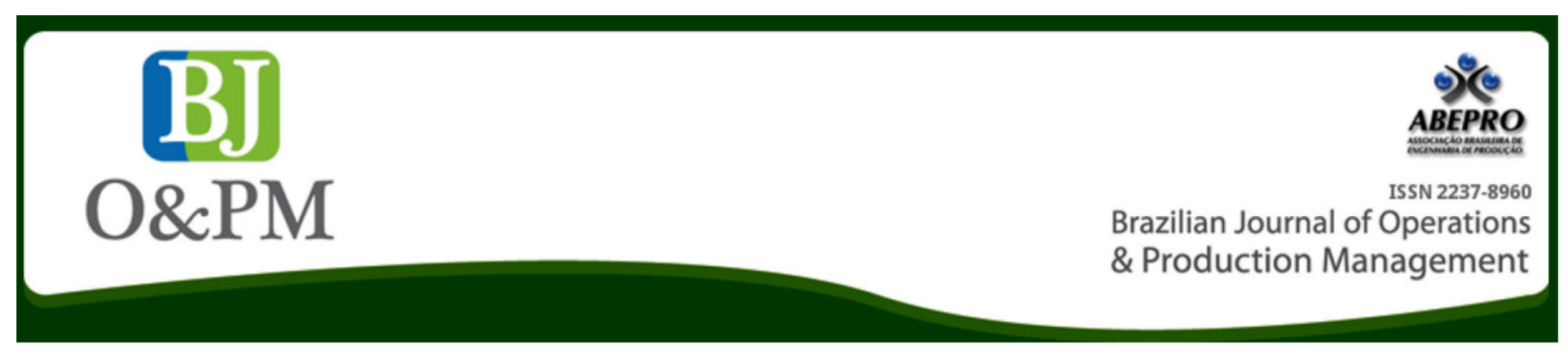

\title{
INTUITION AND MISSING LINKS IN PROJECT MANAGEMENT: A CASE STUDY FROM THE ELBANNA (2015) MODEL
}

Octavio Sanz dos Santos Thomé ${ }^{1}$, Alexandre Ferreira Nascimento ${ }^{2}$, Fernando Carvalho Cid de Araujo ${ }^{1}$, José Rodrigues Farias Filho ${ }^{1}$

1 Fluminense Federal University; 2 Federal Rural University of Rio de Janeiro

\begin{abstract}
Intuition has become a common theme in project management. Elbanna (2015) examines how environment influences intuition and whether reflexivity mediates the link between intuition and project outcomes. By this way, the aim of this work is to apply Elbanna (2015) methodology in a Brazilian firm in order to contribute for to the model validation and to make a literature review, regarding intuition in project management. Our results contribute to science dialog about intuition and reflexivity in decisory process.
\end{abstract}

Keywords: Project Management, intuition, reflexivity 


\section{INTRODUCTION}

Intuition has become a common theme in project management. Researches in project management that address intuition show how it can influence decisions in many kinds of projects, organizations, teams and objectives. Crossan et al. (1999) argue that intuition is a uniquely individual process and it may only happen within a group or organizational context, but the recognition of a pattern or possibility comes from within an individual. From those authors, organizations do not possess this uniquely human attribute.

Elbanna (2015) examines how environment influences intuition and whether reflexivity mediates the link between intuition and project outcomes. In his suggestion for future work, the author affirms that it would be valuable if further research empirically explored the impact of other mediating factors in the link between intuition and project performance, not only because it would provide further validation for the current analysis, but also because it would more firmly open the door to an integration of research on intuition and decision/cognitive styles, on the one hand, and research on project processes, on the other.

Therefore, the aim of this work is to apply Elbanna's (2015) methodology in a Brazilian firm in order to contribute to the model validation and to literature review regarding intuition in project management.

For this, the next section shows a literature review about intuition concepts and developed knowledge and intuition in project management and in decision science. Section 3 describes Elbanna's (2015) methodology applied to this case. Section 4 shows the results and discusses it with other works, mainly Elbanna (2015). Finally, section 5 shows the conclusions and the suggestions for future works.

\section{LITERATURE REVIEW}

\subsection{Intuition and missing links: concepts and knowledge}

Leybourne et Sadler-Smith (2006) remember a definition of intuition as a cognitive conclusion based on the decision maker's previous experiences and emotional inputs. The authors affirm that improvisation and intuition represent two important and related aspects of management in general and of the management of projects in particular.

Nielsen et Pedersen (2014) remember authors who affirm that making decisions based on intuition is increasingly viewed as a viable approach and by using intuition decision makers are able to make fast decisions without conscious thinking, but they still draw on past experience. Whereas ex- pert intuition provides insight into the important process of pattern recognition, entrepreneurial intuition has more to do with innovation and change (Crossan et al., 1999). According those authors, expert intuition supports exploitation; entrepreneurial intuition supports exploration and entrepreneurial intuiting generates new insights.

\subsection{Intuition in decision science}

Antoniou et al. (2013) present the frequencies of the contract type's scores against each criterion in order to decompose the complex selection patterns relating to the participant's choices. The authors affirm that the choice of the most appropriate contract type regarding the method of contractor compensation is essential. In making this choice, decision makers use their own knowledge, experience and intuition according to specific selection criteria they have in mind. Decision making can challenge the individual's basic values, assuming new values, or changing the action. In another way, they could reaffirm their beliefs and values condemning the current action (Motta et Vasconcelos, 2010). Thus, human action would be influenced by new and uncertain elements that go beyond the principles and beliefs such as: new cultures, norms of behavior and learning, in which individuals base their imagined actions.

Minku et Yao (2013), studying methods to improve Software Effort Estimation, used a principled experimental framework for analysis and to provide insights that are not based simply on intuition or speculation.

Kaufmann et al. (2014) affirm that intuitive decisions are made rapidly and without awareness in terms of how conclusions are reached. This approach may allow for a more holistic perspective and may take into account criteria. The authors investigate how the application of rational procedures and experience-based intuition affects the outcomes of supplier selection decisions taken by cross-functional sourcing teams. On the other hand, Hanlon (2011) believes that the heuristic model allows individuals to make decisions quickly with minimal information based on rule of thumb. They enable the simplification of information based on previous experience or knowledge of an area. Heuristics have been particularly identified with intuitive decision making. Heuristics are mental shortcuts individuals use to reduce the complex tasks of assessing probabilities and predicting values to simplify judgmental operations (Hanlon, 2011).

To reinforce the context of intuitive literature, the Nobelist Daniel Kahneman showed how the mind works from advances in cognitive and social psychology, trying to understand the failures of intuitive thinking. According to this author, the intuitive thinking is responsible for automatic operations that are complex, often unconscious, but it explains 
several judgments. This kind of thinking occurs on impulse and is more influential than the experience (Kahneman, 2012). The author argues that individuals often receive automatic responses to problems and, in most cases, these answers come from the skill and experience in dealing with certain situations. However, the intuitive thinking fails when the immediate responses are emotional because they do not have the ability to handle the situation. The author warns that, subjectively, people do not distinguish when intuition and quick thinking are right and when they are wrong. On the other hand, thinking rationally about everything is simply impossible.

\subsection{Intuition in Project Management}

Cho (2006) proposes a framework for updating the estimation of project duration in project networks in which the first step for building a project expert system is to elicit the correlation coefficient of activity durations from expert's knowledge and intuition. Therefore, individual knowledge is as much a reflection of individual's personal interests and histories as it is a reflection of their social identity and the regulating impact of the professional culture, which they embody (Antonacoupolou, 2006).

Leybourne et Sadler-Smith (2006) propose a model of the relationships between rationality and intuition, improvisation and project outcomes and some associated research as shown in figure 1.

Hartman (2008) presents the background to a pilot course that explored an integrative learning model to develop project management and executive thinking skills. In this work, the author affirms that our assessment is intuitive.

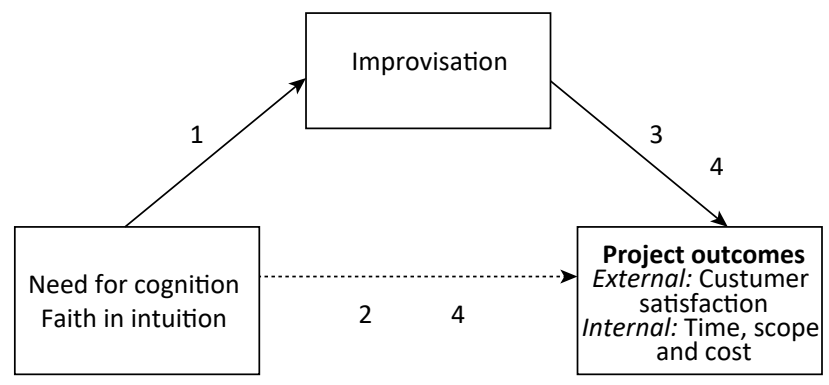

Figure 1. Model of the relationships between rationality and intuition, improvisation and project outcomes

Source: Leybourne et Sadler-Smith (2006)

Sage et al. (2010) examine how understandings in terms of reflexivity might inform project management itself and help shed light on some important assumptions that critical project thinkers will need to address whilst using dialectic thinking.
Dayan et Benedetto (2011) remember that past research has reported the benefits of intuition in new product decision-making, and in his research they built a conceptual model of a new product development team intuition and its effect on the team's ability to generate creative new products. Nonetheless, scholars have recognized metaphors as a critical link in the evolution from individual intuitive insight to shared interpretation (Crossan et al., 1999). Individuals use metaphors to help explain their intuition to themselves and to share it with others, since metaphors involve the transfer of information from a relatively familiar domain.

Rodríguez et al. (2012) analyse the relationships between productivity, team size and other project variables using the International Software Benchmarking Standards Group repository. The results showed that there are statistical correlations between team size, effort, productivity and project duration; however, these correlations are not always what one would expect from the literature or intuition.

Li et al. (2013) provide a means of systematically evaluating the effectiveness of the public participation exercise, or even the whole project, through the measurement of stakeholder satisfaction. They consider that since stakeholder satisfaction assessments with major infrastructure and construction projects are often multi-layered and complicated, uncertain and fuzzy in nature and require approximate reasoning involving human intuition and subjective judgment, it was considered appropriate to adopt the hierarchical fuzzy comprehensive evaluation method for developing a fuzzy satisfaction evaluation model in the study.

Nielsen et Pedersen (2014) investigate decision-making processes in the IT PPM practices of local governments, and discuss how these practices match the normative advice proposed by the IT Project Portfolio Management literature.

\section{METHODOLOGY}

\subsection{Describing Elbanna model}

In his model Elbanna (2015) investigates the relationship between environmental characteristics (measured as competition uncertainty, macro-economic uncertainty and environmental complexity) and intuition, and tests for the mediating effect of reflexivity on intuition-outcomes relationships. Figure 2 describe this idea. 


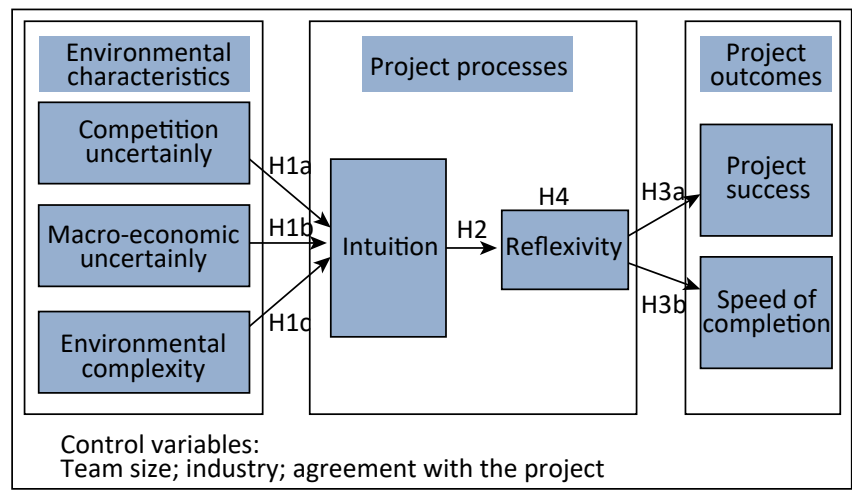

Figure 2. Research Model Source: Elbanna (2015)

For this assessment, Elbanna (2015) built a questionnaire and applied it with 450 managers representing 410 projects from firms located in the United Arab Emirates. From answers, Elbanna (2015) performed a statistic analysis, which makes possible to discuss the importance of intuition and reflexivity in project management even as the identification of missing links.

\subsection{Applying Elbanna model}

As proposed by Elbanna (2015), further research on intuition in project management would be valuable in order to provide further validation to his model and would firmly open the door to an integration of research on intuition and decision/cognitive styles and research on project processes.

By this way, Elbanna's (2015) method was applied in a Brazilian Firm, so that its results are presented in the next section as well as its discussion is performed according to Elbanna's (2015) analysis.

\section{RESULTS AND DISCUSSION}

As described in section three, the application of Elbanna's (2015) model means that the questionnaire built by Said Elbanna was answered by professionals from different areas and, consequently, had different kind of decisions in their tasks, jobs and other responsibilities during the daily processes of the projects.

When applying the questioner in the Brazilian firm, three directors were interviewed and there questions and answers were compiled and are presented in the next Tables 1 to 6 and their comments. After that, a comparison of the answers, results and conclusions is made between Elbanna (2015) and the Brazilian firm, in order to provide the scientific dialog about intuition and reflexivity in decision process and missing links that could be identified.
Table 1. Intuition

\begin{tabular}{|c|c|c|c|c|c|}
\hline \multicolumn{5}{|c|}{$\begin{array}{c}\text { Please, indicate whether you agree or disagree with each state- } \\
\text { ment, considering what happened in the process of planning the } \\
\text { project, which you chose above. }\end{array}$} \\
\hline $\begin{array}{c}\text { Strong- } \\
\text { ly dis- } \\
\text { agree }\end{array}$ & $\begin{array}{c}\text { Unde- } \\
\text { cided }\end{array}$ & $\begin{array}{c}\text { Strongly } \\
\text { agree }\end{array}$ \\
\hline $\begin{array}{c}\text { Participants in planning this proj- } \\
\text { ect relied upon their instincts. }\end{array}$ & 1 & 2 & 3 & $X$ & 5 \\
\hline $\begin{array}{c}\text { Participants in planning this } \\
\text { project tended to rely on their } \\
\text { intuition. }\end{array}$ & 1 & 2 & 3 & $X$ & 5 \\
\hline $\begin{array}{c}\text { Participants in planning this proj- } \\
\text { ect generally made the decisions } \\
\text { that felt right to them. }\end{array}$ & 1 & 2 & 3 & $X$ & 5 \\
\hline $\begin{array}{c}\text { It was more important for par- } \\
\text { ticipants in planning this project } \\
\text { to feel their decisions are right } \\
\text { than to have a rational reason for } \\
\text { them. }\end{array}$ & 1 & 2 & 3 & $X$ & 5 \\
\hline $\begin{array}{c}\text { Participants in planning this proj- } \\
\text { ect trusted their inner feelings } \\
\text { and reactions }\end{array}$ & 1 & 2 & $X$ & 4 & 5 \\
\hline
\end{tabular}

Source: The authors own (2015)

\section{COMMENTS:}

Q.1 - "That is what we expect from "people make the difference". Even if we can provide people with all the information available, and even if all the information available is correct, in the end we expect people to use their experience and take responsibility over their decisions."

Q.2 - "We do not have many projects like this and, at the same time, doing anything in the Northeast of Brazil is always a Challenge. When we had everything ready to start the project, we found that we did not have enough water next to the field where the factory should be built. This is the kind of issue that I do not see a Computer solving."

Q.3 - "Basically, yes but sometimes the owners had to put some priorities in order. Employees not always understand the timing of execution. A lot of planning and no execution never bring a project out of the paper."

Q.4 - "This is cultural in our company. We give them tools to make decisions, but once they decide, we have them responsible for that." 
Table 2. Reflexivity

\begin{tabular}{|c|c|c|c|c|c|}
\hline \multicolumn{5}{|c|}{$\begin{array}{c}\text { Please, tick the appropriate number, according to what hap- } \\
\text { pened during this project. }\end{array}$} \\
\hline $\begin{array}{c}\text { 1. The team investigated and } \\
\text { observed the context and the } \\
\text { progress of the project (e.g., task } \\
\text { performance strategies, goals, } \\
\text { project requirements, the organi- } \\
\text { zational context, etc.). }\end{array}$ & 1 & None & \multicolumn{2}{|c|}{$\begin{array}{c}\text { To some } \\
\text { extent }\end{array}$} & $\begin{array}{c}\text { A great } \\
\text { deal }\end{array}$ \\
\hline $\begin{array}{c}\text { 2. The team adjusted its task per- } \\
\text { formance strategies in response } \\
\text { to changes in the context and } \\
\text { progress of the project. }\end{array}$ & 1 & $x$ & 3 & 4 & 5 \\
\hline $\begin{array}{c}\text { 3. The team spent an adequate } \\
\text { amount of time considering the } \\
\text { likely consequences of its task } \\
\text { activities (e.g. considerations re- } \\
\text { garding usefulness of the project, } \\
\text { compatibility with other projects, } \\
\text { cost, etc.) }\end{array}$ & 1 & $x$ & 3 & 4 & 5 \\
\hline $\begin{array}{c}\text { 4. Strategies and work approach- } \\
\text { es chosen were later checked } \\
\text { for their appropriateness by the } \\
\text { project team. }\end{array}$ & 1 & 2 & $x$ & 4 & 5 \\
\hline
\end{tabular}

Source: The authors own (2015)

\section{COMMENTS:}

Q.1 - "We are never satisfied with the number of appointments that we have to do in a project. The perfect scenario should be having the team making everything work, but we are constantly requested in opinions or even taking some execution under our responsibility. Honestly, I do not know if they are making mistakes on their management and execution as a Team or whether it is a consequence of the years that our management as the owners of a small business that has grown based in a lot of effort and sweat from my partner and I. This is something we constantly keep an eye on."

Q.2 - "Nothing to complement after what was said in Question 1."

Q.3 - "Key point. Again, this can be a consequence of our way of executing, what was made without any planning for many years. By no planning, I mean, no planning at all, not only a formal planning, but also really execution based on experience. Investing money and time to discuss something that we do not expect and we do not want to have happening is still difficult to us. When we have few people controlling the hole process, it seems to be easier to blame this person, instead of having a team with many processes and papers to fill, just to be able to take the responsibility out of who didn't make the mistake."
Q.4 - "Nothing to complement after what was said in Question 3."

Table 3. Project success

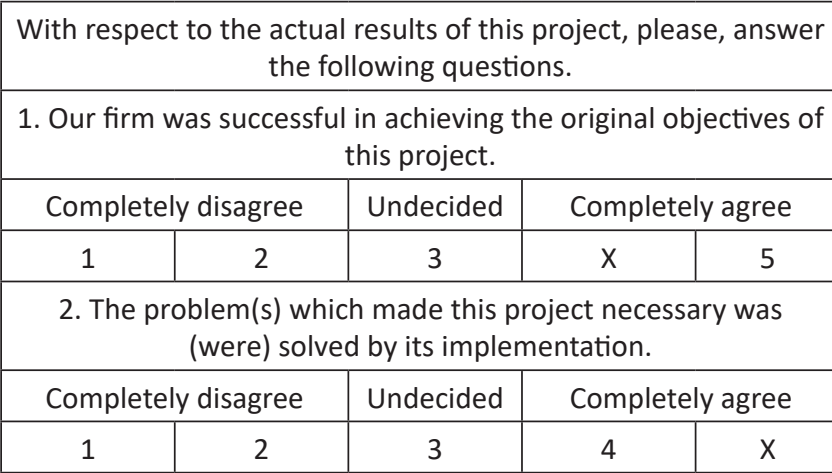

3. Stakeholders were satisfied with the outcomes of this project.

\begin{tabular}{|c|c|c|c|c|}
\hline \multicolumn{2}{|c|}{ Completely disagree } & Undecided & \multicolumn{2}{|c|}{ Completely agree } \\
\hline 1 & 2 & 3 & 4 & $\mathrm{X}$ \\
\hline
\end{tabular}

4. If we had not implemented this project, our firm would have been damaged.

\begin{tabular}{|c|c|c|c|c|}
\hline \multicolumn{2}{|c|}{ Completely disagree } & Undecided & \multicolumn{2}{|c|}{ Completely agree } \\
\hline 1 & 2 & $\mathrm{X}$ & 4 & 5 \\
\hline
\end{tabular}

5. How would you describe the impact of this project on the performance of your firm?

\begin{tabular}{|c|c|c|c|c|}
\hline \multicolumn{2}{|c|}{ Negative impact } & No impact & \multicolumn{2}{c|}{ Positive impact } \\
\hline 1 & 2 & 3 & $X$ & 5 \\
\hline \multicolumn{3}{|c|}{ 6. In general, how do you assess this project now? } \\
\hline Completely unsuccessful & Undecided & Completely successful \\
\hline 1 & 2 & 3 & $X$ & 5 \\
\hline \multicolumn{5}{|c}{ Source: The authors own (2015) }
\end{tabular}

\section{COMMENTS:}

Q.1 - "Considering 5 not only being Successful, but also making it somehow in an easy way, 4 should be the best answer. In Brazil, we have to consider external factors like changing rules, or discovering new rules in the middle of the process. It happened, so we had delays, etc."

Q.2 - "Yes! Even taking some risks of running without everything as planned, the problems will always be solved in a way that will let the project run."

Q.3 - "Yes! Always something to learn for the next implementation, but an overall satisfaction."

Q.4 - "We were market leaders for many years, but technology and logistics are making it easier for smaller players to operate in our market and somehow in any market. It is a big problem that we have, as smaller companies usually basis there strategy on price, what they will later see that 
has no feasibility. This way, what we can do as a bigger company is to invest. Being closer to the mines, distributing our production, makes us more competitive. At the same time, managing a more complex company also brings new challenges."

Q.5 - "As said before, having closer factories to the mines supports us in some logistics situation. When the factory is far from the Mine, processing some ordinary products does not make sense. When we are able to cut fright and other costs, we can process these products and sell them. This is one of the major reasons to have done many factories."

Q.6 - "A project is always an opportunity to learn and develop people. Giving people the opportunity to face real situation and learn is the best that a company can do. The only possibility of improvement in a company is to have the best people and the best-proven people. Necessities will always happen, but success only happens when you have the right people taking care of the right tasks. This said, today we have a factory running and you can say that the project was finished, but a factory is a project that never ends; every day is a new day, so the real success comes from making sure that we have the best people to run it. Even so, we, as the ones in charge, are always taking care of everything from the inside together."

Table 4. Speed of completion

Q.13. With respect to the time you took to implement this project, please answer the following questions.

\begin{tabular}{|c|c|c|c|c|c|}
\hline & $\begin{array}{c}\text { Strongly } \\
\text { dis- } \\
\text { agree }\end{array}$ & \multicolumn{2}{|l|}{ Undecided } & \multicolumn{2}{|c|}{$\begin{array}{c}\text { Strongly } \\
\text { agree }\end{array}$} \\
\hline $\begin{array}{c}\text { This project was completed } \\
\text { in less time than what was } \\
\text { considered normal and } \\
\text { customary for our firm. }\end{array}$ & 1 & 2 & $X$ & 4 & 5 \\
\hline $\begin{array}{c}\text { This project was completed } \\
\text { on or ahead of the original } \\
\text { schedule developed at the } \\
\text { initial project go-ahead. }\end{array}$ & 1 & 2 & $X$ & 4 & 5 \\
\hline $\begin{array}{c}\text { Top management was } \\
\text { pleased with the time it } \\
\text { took us to implement this } \\
\text { project. }\end{array}$ & 1 & $X$ & 3 & 4 & 5 \\
\hline
\end{tabular}

Source: The authors own (2015)

\section{COMMENTS:}

Q.1 and Q.2 - "It was not completed as planned, but in an acceptable time. There is always some room in the first planning, so I can say that we did it on time."

Q.3 - "We will never be completely pleased, but we have to understand the challenges that the team and the proj- ect are facing. We have to understand the tools and level of investment that we are offering to them at the same time. Our budget is always low, our expectations are always high, and the team must bring the project out of the paper this way. This creates an environment of discomfort. Sometimes people think that it is unfair, but in the end, we need to be profitable to survive. In terms of management, even understanding that Brazil is a terrible country to be, with rules changing all the time, we expect the project not to have surprises. This specific project had a mistake in the last minute before execution that made us change a lot of the original planning. Luckily that it was before execution, but it was a mistake that cannot happen."

Table 5. Competition

Indicate if each of the following variables was easy or difficult to predict during this project.

\begin{tabular}{|c|c|c|c|c|c|c|}
\hline & \multicolumn{2}{|c|}{$\begin{array}{c}\text { Easy } \\
\text { to pre- } \\
\text { dict }\end{array}$} & $\begin{array}{c}\text { Un- } \\
\text { de- } \\
\text { cid- } \\
\text { ed }\end{array}$ & \multicolumn{2}{|c|}{$\begin{array}{c}\text { Difficult to } \\
\text { predict }\end{array}$} \\
\hline Changes in competitors prices & 1 & 2 & 3 & $X$ & 5 \\
\hline $\begin{array}{c}\text { Changes in competitors' } \\
\text { strategies }\end{array}$ & 1 & 2 & 3 & 4 & $X$ \\
\hline $\begin{array}{c}\text { Entry of new competitors } \\
\text { Macro-economic uncertainty }\end{array}$ & 1 & $x$ & 3 & 4 & 5 \\
\hline Inflation rate & 1 & 2 & $X$ & 4 & 5 \\
\hline $\begin{array}{c}\text { Exchange rate with foreign } \\
\text { currencies }\end{array}$ & 1 & 2 & 3 & $X$ & 5 \\
\hline Interest rate & 1 & $X$ & 3 & 4 & 5 \\
\hline Economic stability & 1 & 2 & 3 & 4 & $x$ \\
\hline
\end{tabular}

Source: The authors own (2015)

\section{COMMENTS:}

Q.1 - "New companies appear in our market everyday with different strategies. The customers learn how we operate in Brazil more and more and put pressure over prices. This means that it is not that easy to predict prices anymore."

Q.2 - "Technology really makes it easier and easier to be in our market and the actual world scenario presses everybody to be creative. It creates possibilities that different companies use on different ways, what makes it impossible to know the news of the next day."

Q.3 - "Again, we really see a movement of new companies."

Q.4 - "I see to movements here: from the inside out and from the outside in. The first are the new companies in the market and the different strategies that they bring. The sec- 
ond is the world scenario, the interest and dollar rate that is more and more understood by the foreign markets, which also puts pressure over us."

Q.5 - "We have to consider it in Brazil, but we try to be conservative."

Q.6 - "Today this is an important issue. Even working with Heading and other Protections, the fluctuation of the past months can lead us to change prices. Alternatively, it represents the difference between making and losing money."

Q.7 - "The comments about interest rates are similar to the exchange rate. In terms of interest, we try as much as possible not to use the financial market."

Q.8 - "The reason why answering the two previous questions was not easy is exactly because of our Economic stability, or the lack of it. Working in a scenario like what we have today is very delicate, as we cannot have some margin for the protection of our prices and, at the same time, as the risks are a lot higher."

Table 6. Agreement with the project

\begin{tabular}{|c|c|c|c|c|}
\hline \multicolumn{4}{|c|}{ 1. To what extent did you agree or disagree with this project } \\
during its planning?
\end{tabular}

\section{COMMENT:}

Q.1 - "If we do not agree, we do not move forward. In this case, the decision of moving or not is ours, not the team's. Even with almost 1.000 employees, the owners participate in every key decision."

In his work, Elbanna (2015) discusses how intuition is applied in the decisory process, citing works where he affirms that competition uncertainty and environmental complexity are important drives of intuition. By the first battery of questions, we confirm these works, not because of macro-economic uncertainty, but because of environmental features. The high level of an intuitive way of working expressed in answers and the comments that follow suggest that the firm interviewed is implementing a project in an uncertainty environment, which seems to be the greatest drive of intuitive aspect in the decisory process.

By the question about reflexivity, considering the three central elements of reflexivity described by West (2002) (see figure 3), the firm interviewed is closer to the adaptation term than reflection or planning. As can be concluded by the answers and results in terms of project success, in this case, reflexivity is not positively related with project success, which is not in accordance with the studies cited by Elbanna (2015) in his conclusions.

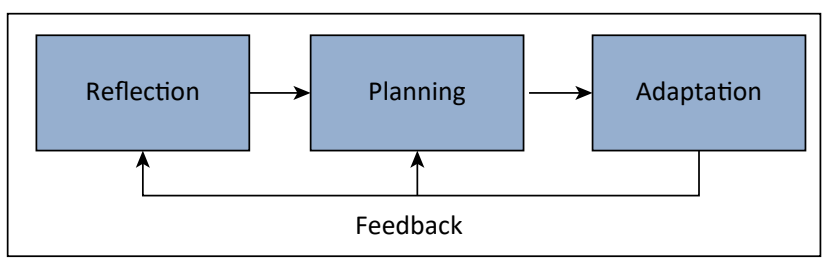

Figure 3. Central elements of reflexivity Source: West (2002)

This lack of reflexivity feature in the firm interviewed is confirmed in the battery questions about completion speed, where professionals did not know about the compliance and project deadline. According to Kahneman's study (2012), it could be explained that there is a tendency for people to attach greater importance to the latest information and more easily accessible in memory, disregarding previous knowledge. For the author, the availability of information and the frequency with which it is released, can affect the individual's perception of a given event, leading to arguments and hasty decisions, since people tend to be more heavily influenced by information that seems to confirm stereotypes or previous convictions.

Macro-economic predictability questionnaire show that the firm works in an environment of high macro-economic uncertainty, mainly because of the country instability. Answers about competitors are not different. Therefore, these results can provide another information proving relation between a macro-economic uncertainty and environment feature, with intuition.

\section{CONCLUSION}

By this work, we could apply Elbanna's (2015) model in a Brazilian firm. We conclude that the objective was achieved, contributing to the research development in intuition and reflexivity at a decisory process in different kinds of firms.

At this point, we remember that the main motivation of this work came from Elbanna's (2015) suggestion, which recommends applying his model in other firms in order to validate and provide more discussion in terms of intuition and reflexivity in industry. From this, we understand that this proposition was achieved and we expect that this article can motivate others on doing the same.

As exposed in the last section, results suggest that intuition influence significantly in the decisory process in the interviewed firm. We understand that other studies could improve this discussion by the application in other firms. 


\section{REFERENCES}

Antonacoupolou, E. (2006), "The relationship between individual and Organizational Learning: New evidence from managerial learning practices", Management Learning Journal, vol. 37 , No. 4, pp. 455-473.

Antoniou, F., Aretoulis, N., Konstantinidisc, D., Kalfakakoub, G. P. (2013), "Complexity in the Evaluation of Contract Types Employed for the Construction of Highway Projects", Procedia - Social and Behavioral Sciences, vol. 74, pp. 448 - 458.

Cho, S. (2006), "An exploratory project expert system for eliciting correlation coefficient and sequential updating of duration estimation", Expert Systems with Applications, vol. 30, pp. 553-560.

Crossan, M. M.; Lane, H.; White, R. E. (1999), "An Organizational Learning Framework: From intuition to Institution", Academy of Management Review, vol. 24, No. 3, pp. 522-537.

Dayan, M., Benedetto, C. A. D. (2011), "Team intuition as a continuum construct and new product creativity: The role of environmental turbulence, team experience, and stress", Research Policy, vol. 40, pp. 276-286.

Elbanna, S. (2015), "Intuition in project management and missing links: Analyzing the predicating effects of environment and the mediating role of reflexivity", International Journal of Project Management, vol. 33, pp. 1236-1248.

Hanlon, P. (2011), "The Role of Intuition in Strategic Decision Making: How Managers' Rationalize Intuition", paper presented at 14th Annual Conference of the Irish Academy of Management, National College of Ireland, Dublin, 31 August 2 September, available at http://arrow.dit.ie/cgi/viewcontent. cgi?article $=1005 \&$ context=buschgracon. (Accessed on 06 April 2016)

Hartman, F. (2008), "Preparing the mind for dynamic management", International Journal of Project Management, vol. 26, pp. 258-267.
Kahneman, D. (2012), Rápido e devagar: duas formas de pensar, Objetiva, Rio de Janeiro, RJ.

Kaufmann, L., Meschnig, G., Reimann, F. (2014), "Rational and intuitive decision-making in sourcing teams: Effects on decision outcomes", Journal of Purchasing \& Supply Management, vol. 20, pp. 104-112.

Leybourne, S., Sadler-Smith, E. (2006), "The role of intuition and improvisation in project management", International Journal of Project Management, vo. 24, pp. 483-492.

Li, T. H. Y., Ng, S. T., Skitmore, M. (2013), “Evaluating stakeholder satisfaction during public participation in major infrastructure and construction projects: A fuzzy approach", Automation in Construction, vol. 29, pp. 123-135.

Minku, L. L., Yao, X. (2013), “Ensembles and locality: Insight on improving software effort estimation", Information and Software Technology, vol. 55, pp. 1512-1528.

Motta, F. C.P.; Vasconcelos, I. F.G. (2010), Teoria Geral da Administração, 3 ed., Revolução, São Paulo, SP.

Nielsen, J. A., Pedersen, K. (2014), IT portfolio decision-making in local governments: Rationality, politics, intuition and coincidences. Government Information Quarterly, vol. 31, pp. 411-420.

Rodríguez, D., Sicilia, M. A., García, E., Harrison, R. (2012), "Empirical findings on team size and productivity in software development", The Journal of Systems and Software, vol. 85, pp. $562-570$.

Sage, D., Dainty, A., Brookes, N. (2010), "A consideration of reflexive practice within the critical projects movement", International Journal of Project Management, vol. 28, pp. 539-546.

West, M.A. (2002), "Sparkling fountains or stagnant ponds: an integrative model of creativity and innovation implementation in work groups", Appl. Psychol. Vol. 51, pp. 355-387. 